\title{
Field Performance of Quatity Protein Maize With Zinc and Magnesium Fertilizers in the Sub-Humid Savanna of Nigeria
}

\author{
U. F. Chiezey ${ }^{1}$ \\ ${ }^{1}$ Department of Agronomy, Faculty of Agriculture, Ahmadu Bello University, Zaria, Nigeria \\ Correspondence: U. F. Chiezey, Department of Agronomy, Faculty of Agriculture, Ahmadu Bello University, \\ Zaria, Nigeria. E-mail: uchechiezey@yahoo.com; uchechiezey@gmail.com
}

$\begin{array}{ll}\text { Received: December 12, } 2013 & \text { Accepted: January 3, } 2014 \quad \text { Online Published: February 15, } 2014 \\ \text { doi:10.5539/jas.v6n3p84 } & \text { URL: http://dx.doi.org/10.5539/jas.v6n3p84 }\end{array}$

\begin{abstract}
Field experiments were conducted for three years $(2006-2008)$ in Samaru $\left(11^{\circ} 11^{\prime} \mathrm{N}, 7^{\circ} 38^{\prime} \mathrm{E}\right) 686 \mathrm{~m}$ above sea level in Nigeria. The objective was to test the response of two Quality Protein Maize (QPM) varieties (SAMMAZ-14 and SAMMAZ-11) to four levels each of Zinc and Magnesium $(0,1.25,2.5$ and $5.0 \mathrm{~kg})$ using their carbonates. The experiments were arranged in all possible factorial combinations and laid out as randomised complete block design (RCBD) and replicated three times. The two varieties tested did not differ significantly in all the parameters evaluated except for the number of days to $50 \%$ tasselling. Grain yield ranged between $1.9-2.0$ $\mathrm{t} / \mathrm{ha}$ when averaged over both years which was quite below the $5.0 \mathrm{t} / \mathrm{ha}$ potential. Zinc application had no significant influence on most characters evaluated except total dry matter per hectare in 2006 when the application of $1.25 \mathrm{~kg} \mathrm{2n} / \mathrm{ha}$ produced the highest TDM. Grain yield per hectare remained unchanged with changes in Zinc rate. Magnesium application influenced grain yield on 2008 only when $1.25 \mathrm{~kg} \mathrm{Mg} / \mathrm{ha}$ increased yield compared with plots with $5.0 \mathrm{~kg} \mathrm{mg} / \mathrm{ha}$. When averaged over the three years, $\mathrm{Mg}$ application did not significantly influence grain yield, but increased protein yield. Grain yield correlated positively and significantly with leaf area index $(\mathrm{r}=$ $\left.0.13^{* *}\right)$, plant height $\left(\mathrm{r}=0.26^{*}\right)$, TDM $\left(\mathrm{r}=0.21^{* *}\right)$ and protein yield $\left(\mathrm{r}=0.97^{* *}\right)$. Protein content of grain remained unchanged with changes in Zinc and Magnesium rates at $8 \%$
\end{abstract}

Keywords: Maize, nutrients, protein

\section{Introduction}

Maize (Zea mays L.) is an important food crop in Nigeria, consumed in different forms, either roasted, boiled, made into a meal and eaten with soup or stew, or into a light poridge. It is also the basic ingredient of animal feed, particularly poultry feed. Many Nigerian diets are based on starchy staples such as sorghum (Sorghum bicolor L. (Moench), millet (Pennisetum typhoides Stapf and Huhbard), rice (Oryza sutiva L.) and root crops mostly yams (Dioscorea spp), cassava (Manihot esculentus Crantz) and sweet potatoes (Ipomea batatas L.). Protein consumption is low, particularly animal protein because of scarcity and cost. This obvious malnutrition calls for increase in protein intake to alleviate the obvious debilities casued by inadequate protein intake.

The development of Quality Protein Maize (QPM) with high content of two of the essential amino acids Lysine and Tryptophan, lacking in ordinary maize will help to ameliorate the protein - deficient diets. Badu - Apraku and Fontem - Lun (2010) reported that protein of QPM has $90 \%$ of the relative value (RV) of milk compared with $40 \%$ for ordinary maize. Akuanmo - Boateng (2003) observed that children fed QPM had signifcantly fewer sick days and grew healthier than children fed ordinary maize. Therefore, growing and consuming QPM may alleviate some of the nutritional problems of the population with predominantly starchy diets.

The easiest approach to increase QPM consumption is to increase the production. The sub-humid Savanna which is the centre of maize production in Nigeria is characterised by poor soil, low in $\mathrm{N}$ and $\mathrm{P}$, the major nutrients for maize growth. Trials in the savanna with fertilizers have proved that application of $100-120 \mathrm{~kg} \mathrm{~N}, 26.4 \mathrm{~kg} \mathrm{P}$ and $48 \mathrm{~kg} \mathrm{~K}$ per hectare was sufficient for high maize yield (Goldworthy, 1967; Jones, 1973; Balasubramanian et al., 1978; Ologunde \& Ogunlela, 1984; Mbagwu, 1990; Chiezey \& Shamsudeen, 2004; Jaliya, 2012). Virtually all fertilizer recommendations are based on the three major elements, N, P and K without consideration for secondary and micronutrients which are removed during crop harvesting and never replenished. This may lead to nutrient imbalance (Lombin, 1983). Trials with micronutrients in savanna are few and in some areas indicate low levels of magnesium and zinc (Osiname, 1972; Lombin, 1983). Iwuafor et al. (1991) noted that maize responded positively 
to zinc application where the extractable $\mathrm{Zn}$ fell below $1.0 \mathrm{Mg} \mathrm{Kg}^{-1^{*}}$ Anonymous (1989) recommended $5 \mathrm{~kg} \mathrm{Zn}$ per hectare for hybrid maize. Chiezey (1999) observed that soybean did not respond to zinc and magnesium applications in the northern Guinea Savanna and that grain yield declined with the application of zinc and magnesium. Cropping system has inensified in the savanna and most crop residues are removed from farms for feeding livestock, tatching, fencing and firewood, thereby reducing the levels of these nutrients without any effort at replenishment. This study was, therefore, undertaken to evaluate the response of two QPM varieties to different levels of $\mathrm{Zn}$ and $\mathrm{Mg}$ in the sub-humid savanna ecological zone of Nigeria.

\section{Materials and Methods}

Table 1. Rainfall data at 10 days interval in Samaru 2006 - 2009

\begin{tabular}{|c|c|c|c|}
\hline \multirow{2}{*}{ Month } & \multicolumn{3}{|c|}{ Rainfall (mm) } \\
\hline & 2006 & 2007 & 2008 \\
\hline \multicolumn{4}{|l|}{ April } \\
\hline $1-10$ & - & 14.4 & 20.4 \\
\hline $11-20$ & - & - & - \\
\hline $21-30$ & 1.8 & 44.3 & 52.2 \\
\hline \multicolumn{4}{|l|}{ May } \\
\hline $1-10$ & 47.0 & 96.0 & 23.8 \\
\hline $11-20$ & 83.4 & 4.2 & 32.2 \\
\hline $21-31$ & 72.1 & 69.2 & 52.9 \\
\hline \multicolumn{4}{|l|}{ June } \\
\hline $1-10$ & 4.4 & 60.0 & 68.1 \\
\hline $11-20$ & 34.7 & 39.4 & 27.9 \\
\hline $21-30$ & 87.4 & 107.8 & 15.7 \\
\hline \multicolumn{4}{|l|}{ July } \\
\hline $1-10$ & 17.8 & 27.4 & 63.4 \\
\hline $11-20$ & 171.8 & 32.4 & 18.2 \\
\hline $21-31$ & 42.6 & 168.8 & 148.2 \\
\hline \multicolumn{4}{|l|}{ August } \\
\hline $1-10$ & 74.8 & 51.1 & 122.6 \\
\hline $11-20$ & 43.5 & 177.0 & 124.8 \\
\hline $21-31$ & 102.8 & 146.2 & 105.8 \\
\hline \multicolumn{4}{|c|}{ September } \\
\hline $1-10$ & 76.2 & 16.4 & 114.0 \\
\hline $11-20$ & 126.1 & 3.5 & 58.0 \\
\hline $21-30$ & 78.1 & 12.0 & 45.8 \\
\hline \multicolumn{4}{|l|}{ Oct. } \\
\hline $1-10$ & 21.8 & 4.9 & 67.2 \\
\hline $11-20$ & 6.7 & 3.4 & 21.8 \\
\hline $21-31$ & - & - & - \\
\hline \multicolumn{4}{|l|}{ Nov } \\
\hline $1-10$ & - & - & - \\
\hline TOTAL & 1093.0 & 1080.4 & 1183.0 \\
\hline
\end{tabular}

Field experiments were conducted during the rainy seasons of 2006, 2007 and 2008 at the Institute for Agricultural Research (IAR), Ahmadu Bello University, Samaru, Zaria (1 $\left.1^{\circ} 11^{\prime} \mathrm{N} 7^{\circ} 38^{\prime} \mathrm{E}\right), 686 \mathrm{~m}$ above sea level. Samaru is located in the northern Guinea Savanna with an annual rainfall of 11,00 mm distributed between April and October (Kowal \& Knabe, 1972). The objective was to test the response of two QPM varieties (SAMMAZ-14 and SAMMAZ-11) to four levels each of zinc and magnesium $(0,1.25,2.5$ and $5.0 \mathrm{~kg} / \mathrm{ha})$ using their carbonates in all possible factorial combinations, using a randomised complete block design with three replications. 
Rainfall data were collected for the three years from the IAR metrological station (Table 1). Soil samples were randomly collected and later bulked from the sites before fertilizer application and analysed for physico-chemical properties (Table 2). The QPM varieties were released by IAR, Samaru. Both are medium maturing $(100-120$ days) and have yield potential of $5 \mathrm{t} / \mathrm{ha}$ (Ado et al., 2009). Both are resistant to striga (Striga hermontheca) which is endemic in the zone. Plantings were done end of June each year. Two seeds of each variety were planted on $75 \mathrm{~cm}$ row ridges at intra-row spacing of $25 \mathrm{~cm}$. The crop was thinned to one plant per stand at three weeks after sowing to give a plant density of $53,333 \mathrm{pl} / \mathrm{ha}$.

$\mathrm{Zn}$ and $\mathrm{Mg}$ using the carbonates at $0,1.25,2.5$ and $5.0 \mathrm{~kg} / \mathrm{ha}$ in all possible factorial combinations were side-banded after planting. In order to facilitate handling of the nutrients, each fertilizer rate was mixed with one kilogram of pure river sand which was thoroughly washed and rinsed with de-ionised water. A basal dose of 120 $\mathrm{kg} \mathrm{N}, 26.4 \mathrm{~kg} \mathrm{P}$ and $49 \mathrm{~kg} \mathrm{~K}$ per hectare were applied at planting using the compound fertilizer 20:10:10. The gross plot was $6 \mathrm{~m} \times 6 \mathrm{~m}\left(36 \mathrm{~m}^{2}\right)$ and the net plot was $3 \mathrm{~m} \times 6 \mathrm{~m}\left(18 \mathrm{~m}^{2}\right)$.

Five plants per plot were sampled to determine the effects of the treatments on leaf area index (LAI), flag leaf area (FLA), Ear leaf area (ELA), number of days to $50 \%$ tasselling, plant height at harvesting, total dry matter (TDM) per hectare at harvesting, grain weight per plant, grain yield per hectare, 100 -seed weight and protein yield per hectare. $\mathrm{N}$ content of seed was analysed for the calculation of protein content and yield.

The data collected were analysed for individual years and the years combined using the analysis of variance (Snedecor \& Cochran, 1967). The means were compared using the multple range test (Duncan, 1955).

Table 2. Physical and chemical properties of the top soil $(0-30 \mathrm{~cm})$ of the experimental fields for three years 2006 , 2007 and 2008

\begin{tabular}{llll}
\hline \multirow{2}{*}{ Composition } & \multicolumn{3}{c}{ Year } \\
\cline { 2 - 4 } & 2006 & 2007 & 2008 \\
\hline Physical characteristics & 180 & 80 & 80 \\
Clay (g/kg) & 160 & 80 & 100 \\
Silt $(\mathrm{g} / \mathrm{kg})$ & 660 & 840 & 820 \\
Sand $(\mathrm{g} / \mathrm{kg})$ & Sandy loam & Sandy loam & Sandy loam \\
Textural class & & & \\
Chemical characteristics & & 5.0 & 5.4 \\
$\mathrm{pH}\left(\mathrm{H}_{2} 0\right)$ & 5.2 & 4.8 & 5.0 \\
$\mathrm{pH}\left(\mathrm{Ca} \mathrm{CL}_{2}\right)$ & 4.8 & 0.15 & 0.15 \\
Organic carbon $(\mathrm{g} / \mathrm{kg})$ & 0.20 & 2.2 & 2.0 \\
Available P (mg/kg) & 1.8 & 1.5 & 1.2 \\
Total N g/kg & 1.1 & & \\
Exchangeable bases & & 1.5 & 1.4 \\
Ca (Cmol/kg Soil) & 2.0 & 0.3 & 0.3 \\
Mg “ & 0.2 & 0.2 & 0.2 \\
K “ & 0.2 & 3.8 & 4.0 \\
CEC “ & 4.1 & & \\
Micronutrient & & 1.0 & 0.9 \\
Zn (ppm) & 1.9 &
\end{tabular}

\section{Results}

The results were the obtained for three years, 2006 - 2008. Rainfall varied among the three years both in total amount and distribution and this was reflected in the gain yield (Table 1). Highest grain yield was obtained in 2006, probably because of a better rainfall distribution.

Protein content of the grain was not influenced by any of the treatments and ranged between 7.8 and $8.2 \%$ with a mean of $8.0 \%$. Leaf area index (LAI), flag leaf area and ear leaf area at $50 \%$ silking were determined at $50 \%$ silking (Table 3,). The two varieties did not significantly differ in any of these three attributes. Similarly, neither zinc not magnesium application bad any significant effect on these parameters. 
Table 3. Leaf area index, flag leaf area and ear leaf area of two Quality protein maize varieties as influenced by different rates of $\mathrm{Zn}$ and $\mathrm{Mg}$ fertilizers in Samaru (mean of three years) 2006 - 2008

\begin{tabular}{llll}
\hline Treatment & LAI & Flag leaf area $\left(\mathrm{CM}^{2}\right)$ & Ear leaf area $\left(\mathrm{CM}^{2}\right)$ \\
\hline Variety & & & \\
SAMMAZ - 14 & 2.7 & 38.8 & 78.1 \\
SAMMAZ - 11 & 2.7 & 39.0 & 78.1 \\
Mean & 2.7 & 38.9 & 78.1 \\
SED & NS & NS & NS \\
Zn rate (kg/ha) & & & \\
0 & 2.7 & 39.3 & 78.1 \\
1.25 & 2.7 & 39.7 & 78.1 \\
2.50 & 2.7 & 38.5 & 78.6 \\
5.0 & 2.7 & 38.1 & 77.7 \\
SE+ & NS & & NS \\
Mg rate (kg/ha) & & & \\
0 & 2.7 & 37.8 & 78.5 \\
1.25 & 2.7 & 39.1 & 78.1 \\
2.50 & 2.7 & 39.1 & 78.2 \\
5.0 & 2.7 & 39.6 & 77.8 \\
SE+ & NS & NS & NS \\
\hline
\end{tabular}

Means within same treatment group and column followed by same letter(s) are not significantly different at $5 \%$ level of probability using DMRT.

Number of days to $50 \%$ tasselling differed between the two varieties (Table 4). Sammaz-11 tasselled later than Sammaz-14. Neither Zinc nor Magnesium application had significant influence on the number of days to $50 \%$ tasselling.

Plant height at harvesting was similar for both varieties (Table 4). Application of $1.25 \mathrm{~kg} \mathrm{Zn} / \mathrm{ha}$ increased plant height by $4.1 \%$ compared with plots without $\mathrm{Zn}$. Increasing the level of $\mathrm{Zn}$ above $1.25 \mathrm{~kg} / \mathrm{ha}$ did not influence plant height. Application of Mg depressed plant height in 2007 only, but averaged over the three years $\mathrm{Mg}$ application did not significantly influence plant height.

Table 4. Number of days to $50 \%$ tasselling and plant height at harvesting of two Quality Protein Maize varieties as influenced by different rates of $\mathrm{Zn}$ and Mg fertilizers in Samaru (Mean of three years) 2006 - 2008

\begin{tabular}{lll}
\hline Treatment & $\begin{array}{l}\text { Number of days to } \\
50 \% \text { tasselling }\end{array}$ & $\begin{array}{l}\text { Plant height at } \\
\text { harvesting }(\mathrm{cm})\end{array}$ \\
\hline Variety & & \\
SAMMAZ - 14 & $58.2 \mathrm{~b}$ & 208.9 \\
SAMMAZ - 11 & $58.8 \mathrm{a}$ & 206.3 \\
Mean & 58.5 & 207.6 \\
SED & 0.13 & NS \\
Zn rate (kg/ha) & & \\
0 & 58.3 & 202.46 \\
1.25 & 58.4 & $210.7 \mathrm{a}$ \\
2.50 & 58.5 & $209.0 \mathrm{ab}$ \\
5.0 & 58.7 & $208.3 \mathrm{ab}$ \\
$\mathrm{SE}+$ & $\mathrm{NS}$ & 2.40 \\
$\mathrm{Mg}$ rate $(\mathrm{kg} / \mathrm{ha})$ & & \\
0 & 58.3 & 206.5 \\
1.25 & 58.3 & 210.8 \\
2.50 & 58.5 & 206.3 \\
5.0 & 58.5 & 206.7 \\
SE+ & NS & NS \\
\hline
\end{tabular}

Means within same treatment group and column followed by same letter(s) are not significantly different at $5 \%$ level of probability using DMRT. 
Table 5. Total dry matter at harvesting per plant are of Quality Protein Maize varieties with varying levels of $\mathrm{Zn}$ and Mg fertilizers in Samaru (Mean of three years) 2006-2008

\begin{tabular}{lllll}
\hline Treatment & \multicolumn{5}{c}{ Total dry matter (kg/ha) } \\
\hline Variety & 2006 & 2007 & 2008 & Mean \\
SAMMAZ - 14 & 3041.6 & 2510.4 & 3770.7 & 3107.6 \\
SAMMAZ - 11 & 3037.0 & 2073.9 & 3617.9 & 2909.6 \\
Mean & 3039.3 & 2292.2 & 3694.3 & 3008.6 \\
SED & $\mathrm{NS}$ & $\mathrm{NS}$ & $\mathrm{NS}$ & $\mathrm{NS}$ \\
Zn rate (kg/ha) & & & & \\
0 & $3157.4 \mathrm{ab}$ & 2199.0 & 3800.8 & 3052.4 \\
1.25 & $3240.7 \mathrm{a}$ & 2472.0 & 3657.2 & 3123.3 \\
2.50 & $2995.3 \mathrm{ab}$ & 2530.1 & 3569.3 & 3031.6 \\
5.0 & $2763.8 \mathrm{~b}$ & 1967.5 & 3749.9 & 2827.1 \\
SE+ & 150.99 & $\mathrm{NS}$ & $\mathrm{NS}$ & $\mathrm{NS}$ \\
Mg rate (kg/ha) & & & & \\
0 & 3166.6 & 2366.0 & 2560.1 & 3030.9 \\
1.25 & 3023.1 & 2358.8 & 4009.0 & 3130.3 \\
2.50 & 2847.1 & 2101.6 & 3578.6 & 2842.4 \\
5.0 & 3120.3 & 2342.5 & 3629.5 & 3030.8 \\
SE+ & $\mathrm{NS}$ & $\mathrm{NS}$ & $\mathrm{NS}$ & $\mathrm{NS}$ \\
\hline
\end{tabular}

Means within same treatment group and column followed by same letter(s) are not significantly different at 5\% level of probability using DMRT.

Table 6. Grain weight per plant and 100 - grain weight of Quality Protein Maize as influenced by different rates of $\mathrm{Zn}$ and Mg fertilizers in Samaru (Mean of three years) 2006-2008

\begin{tabular}{lll}
\hline $\begin{array}{l}\text { Treatment } \\
\text { Variety }\end{array}$ & $100-$ grain wt $(\mathrm{g})$ & grain wt/plant $(\mathrm{g})$ \\
\hline SAMMAZ - 14 & 21.5 & 108.0 \\
SAMMAZ - 11 & 21.6 & 113.2 \\
Mean & 21.6 & 110.6 \\
SED & $\mathrm{NS}$ & $\mathrm{NS}$ \\
Zn rate (kg/ha) & & \\
0 & 21.5 & $115.8 \mathrm{a}$ \\
1.25 & 21.0 & $102.1 \mathrm{~b}$ \\
2.50 & 21.8 & $112.4 \mathrm{ab}$ \\
5.0 & 21.7 & $112.0 \mathrm{ab}$ \\
$\mathrm{SE}+$ & $\mathrm{NS}$ & 3.94 \\
$\mathrm{Mg}$ rate $(\mathrm{kg} / \mathrm{ha})$ & & \\
0 & 20.9 & $106.0 \mathrm{ab}$ \\
1.25 & 21.5 & $117.2 \mathrm{a}$ \\
2.50 & 21.3 & $104.3 \mathrm{~b}$ \\
5.0 & 22.3 & $114.9 \mathrm{ab}$ \\
$\mathrm{SE}+$ & $\mathrm{NS}$ & $\mathrm{NS}$ \\
\hline
\end{tabular}

Means within same treatment group and column followed by same letter(s) are not significantly different at 5\% level of probability using DMRT.

Total dry matter at harvesting was similar for both varieties (Table 5). The application of $5.0 \mathrm{~kg} \mathrm{Zn} / \mathrm{ha}$ depressed total dry matter by $14.7 \%$ compared with plots where $1.25 \mathrm{~kg} / \mathrm{ha}$ of $\mathrm{Zn}$ was applied. Total dry matter was similar with $0,1.25$ and $2.5 \mathrm{~kg} \mathrm{Zn} / \mathrm{ha}$. Magnesium application did not influence maize TDM/ha in any of the years and when averaged over the three years. Grain weight per plant were similar for both varieties (Table 6). Grain weight per plant ranged between 108.0 - 113.2 g. Zn application influenced grain weight per plant. Zinc application reduced grain weight when averaged over the three years. Magnesium application also influenced grain weight per plant. The application of $1.25 \mathrm{~kg} \mathrm{Mg} / \mathrm{ha}$ increased grain weight by $20.1 \%$ in 2007 when compared with plots without $\mathrm{Mg}$. When averaged over the years, increasing Mg rate from 1.25 to $2.5 \mathrm{~kg} \mathrm{Mg} /$ ha reduced grain weight 
per plant by $11.0 \%$. No interactions were significant. 100 -seed weight was not influenced by any of the treatments (Table 6). 100-seed weight ranged between 20 and $22 \mathrm{~g}$.

Table 7. Grain yield per hectare of Quality Protein Maize varieties as influenced by $\mathrm{Zn}$ and Mg fertilizers in Samaru (Mean of three years) $2006-2008$

\begin{tabular}{lllll}
\hline Treatment & \multicolumn{4}{l}{ Grain yield (kg/ha) } \\
\hline Variety & 2006 & 2007 & 2008 & Mean \\
SAMMAZ - 14 & 2432.8 & 1518.0 & 1782.3 & 1911.1 \\
SAMMAZ - 11 & 2609.6 & 1586.2 & 1872.9 & 2022.9 \\
Mean & 2521.2 & 1552.1 & 1827.6 & 1967.0 \\
SED & NS & NS & NS & NS \\
Zn rate (kg/ha) & & & & \\
0 & 2456.7 & 1350.3 & 1718.7 & 1841.9 \\
1.25 & 2723.9 & 1521.5 & 1679.6 & 1975.0 \\
2.50 & 2463.1 & 1583.9 & 1957.0 & 2001.3 \\
5.0 & 2441.1 & 1752.7 & 1955.1 & 2049.6 \\
SE+ & NS & NS & NS & NS \\
Mg rate (kg/ha) & & & & \\
0 & 2582.7 & 1414.9 & $1764.5 \mathrm{ab}$ & 1920.7 \\
1.25 & 2521.4 & 1846.6 & $2097.9 \mathrm{a}$ & 2155.9 \\
2.50 & 2590.8 & 1390.2 & $1624.5 \mathrm{~b}$ & 1868.5 \\
5.0 & 2389.8 & 1554.7 & $1823.5 \mathrm{ab}$ & 1922.9 \\
SE+ & $\mathrm{NS}$ & $\mathrm{NS}$ & $\mathrm{NS}$ & $\mathrm{NS}$ \\
\hline
\end{tabular}

Means in same treatment group and column followed by similar letter(s) are not significantly different at $5 \%$ level of probability using DMRT.

Table 8. Protein yield per hectare of QPM varieties as influenced by different rates of $\mathrm{Zn}$ and Mg fertilizers in Samaru (Mean of three years) $2006-2008$

\begin{tabular}{lllll}
\hline Treatment & \multicolumn{4}{c}{ Protein yield (kg/ha) } \\
\cline { 2 - 5 } Variety & 2006 & 2007 & 2008 & Mean \\
\hline SAMMAZ - 14 & 194.7 & 121.9 & 140.5 & 152.3 \\
SAMMAZ - 11 & 209.1 & 126.9 & 151.4 & 162.5 \\
Mean & 201.9 & 124.4 & 146.0 & 157.4 \\
SED & NS & NS & NS & NS \\
Zn rate (kg/ha) & & & & \\
0 & 196.5 & 108.9 & 140.5 & 148.7 \\
1.25 & 217.9 & 121.7 & 135.3 & 158.3 \\
2.50 & 197.1 & 126.7 & 162.2 & 162.0 \\
5.0 & 196.0 & 140.2 & 145.9 & 160.0 \\
SE+ & NS & NS & NS & NS \\
Mg rate (kg/ha) & & & & \\
0 & 206.6 & 113.2 & 140.5 & $153.4 \mathrm{ab}$ \\
1.25 & 201.8 & 148.8 & 168.0 & $172.8 \mathrm{a}$ \\
2.50 & 207.9 & 111.2 & 127.3 & $148.8 \mathrm{~b}$ \\
5.0 & 191.2 & 124.4 & 141.8 & $154.5 \mathrm{ab}$ \\
SE+ & $\mathrm{NS}$ & $\mathrm{NS}$ & $\mathrm{NS}$ & 7.86 \\
\hline
\end{tabular}

Means in same treatment group and column followed by similar letter(s) are not significantly different at $5 \%$ level of probability using DMRT. 
Grain yield per hectare did not differ significantly between the two QPM varieties (Table 7). Grain yield was highest in 2006 compared with other years. Application of $\mathrm{Zn}$ did not influence grain yield in any of the years and when averaged over the three years. The application of $1.25 \mathrm{~kg} \mathrm{Mg} / \mathrm{ha}$ increased grain yield by $18.8 \%$ compared with plots without $\mathrm{Mg}$ but sifnificantly reduced grain yield by $22.5 \%$ by increasing the $\mathrm{Mg}$ level to $5.0 \mathrm{~kg} \mathrm{Mg} / \mathrm{ha}$. When averaged over the three years, application of $\mathrm{Mg}$ had no significant influence on grain yield of QPM.

Protein yield followed same pattern with grain yield, being similar for the two varieties and not changing with $\mathrm{Zn}$ application (Table 8). Magnesium application influenced protein yield when averaged over the three years. Increasing Magnesium rate from 1.25 to $2.5 \mathrm{~kg} \mathrm{Mg} / \mathrm{ha}$ reduced protein yield by $13.9 \%$.

Grain yield per hectare correlated positively and significantly with TDM $\left(\mathrm{r}=21^{* *}\right), \mathrm{LA}\left(\mathrm{r}=0.13^{* *}\right)$, plant height $(\mathrm{r}$ $\left.=0.26^{*}\right)$ and protein yield $\left(\mathrm{r}=0.97^{*}\right)$.

\section{Discussion}

Table 1 shows the total rainfall and distribution at 10 days interval in the three years of the study. Grain yield was better in 2006 because of a more even distribution of rain. In 2007, rainfall declined during grain formation while in 2008, exersive rainfall during tasselling could have resulted in pollen wash out, both factors resulting in reduction in number of grains per cob. Maize cobs in 2006 were completely filled with grains resulting in higher yields.

The soils of the experimental fields reflected the characteristics of the savanna, low $\mathrm{pH}$, low levels of $\mathrm{N}$ and $\mathrm{P}$ but high in $\mathrm{K}$ (Table 2). The micronutrient status of the soils ranged from medium to low. Grain yield per hectare responded positively to Magnesium in 2008 because of the low level of the nutrient in the soil $(<1.0 \mathrm{cmol} / \mathrm{ha}$ of soil).

The varieties did not significantly differ from each other in most of the parameters measured. Leaf area index, flag leaf area, ear leaf area, plant height at harvesting, total dry matter per hectare, 100-grain weight and grain yield per hectare were similar in both varieties. Protein yield per hectare were similar in both varieties. The similarities in these two QPM varieties could be attributed to their common genetic background. Both were bred from same parents. They only differed in their number of days to $50 \%$ tasselling which was not much, 58.2 and 58.8 days. This is statistically possible but in practice, these two could be assumed to tassel same period.

The application of Zinc did not influence most of the parameters such as LAI, and ear leaf area probably because of the moderate to high levels of the nutrient in the soil. Zinc application increased plant height when averaged over the three years. With $1.25 \mathrm{~kg} \mathrm{Zn}$ per hectare, plant height increased significantly compared with plots without $\mathrm{Zn}$. Total dry matter per hectare was increased by the application of $1.25 \mathrm{~kg} \mathrm{Zn} /$ ha probably because of the moderate level in the soil. This was not reflected in the grain yield. Total protein yield which correlated positively with grain yield $\left(\mathrm{r}=0.9^{* *}\right)$ was also not influenced significantly by zinc application.

The application of Magnesium influenced grain weight per plant and protein yield per hectare. Although grain yield increased with the application of $1.25 \mathrm{~kg} \mathrm{Mg} / \mathrm{ha}$, the increase was not significant probably because of the moderate levels of $\mathrm{Mg}$ in the soil. Soil analysis showed that the level of $\mathrm{Mg}$ in the soil was moderate and therefore spectacular responses were not obtained. Increasing the levels of both nutrients above $1.25 \mathrm{~kg} / \mathrm{ha}$ tended to reduce grain yield, implying that the nutrient may be reaching toxicity levels. Protein yield increased with $\mathrm{Mg}$ application because the nutrient is essential for protein synthesis (Mengel \& Kirkby, 1987). The positive and significant correlations between grain yield and some growth parameters indicate their contributions to yield. Leaf area index which is a measure of total ground cover reflects the photosynthetic machinery for capturing and conversion of solar energy into assimilates for eventual translocation to grain. Therefore, increase in LAI up to the optimum eventually increased grain yield. Similarly, high TDM also translated into high grain yield as more photosynthates were eventually translocated to the sink, and in this instance the grain. Plant height has been shown also to increase grain yield in some instances. Tall plants have more or larger leaves that may promote high photosynthetic activity, therefore more assimilates for grain filling.

The study has shown that Magnesium and Zinc levels may still be adequate in the savanna. However, there is a need for constant monitoring of these nutrients with the intersification of crop production and utilisation of crop refuse for other purposes instead of returning same to the soil for soil amendment. Mg not exceeding $1.25 \mathrm{kgMg} / \mathrm{ha}$ may be applied to increase protein yield per hectare as deficiency of $\mathrm{Mg}$ has been shown to reduce protein synthesis. 


\section{References}

Ado, S. G., Showemimo, F. A., Falaki, A. M., Alabi, S. O., \& Abdullahi, U. S. (2009). Proposal for the registration and release of Quality Protein Maize variety SAMMAZ-14 (Obatanpa). Department of Plant Science, Institute for Agricultural Research, Ahmadu Bello University, Zaria.

Akuamoa-Boateng, A. (2002). Quality protein maize infant feeding trials in Ghana. Ashanti, Ghana: Ghana Health Service.

Anonymous. (1989). Fertilizer use and management for crops in Nigeria (Series No. 2).

Badu-Apraku, B. and Fontem-Lun, A. (2010). Grain yield response of normal and Quality Protein Maize cultivars in stress and non-stress environments. Agronomy Journal, 102, 381-394. http://dx.doi.org/10.2134/agronj2009.0229

Balasubramanian, V., Nnadi, L. A., \& Mokwunye, A. U. (1978). Fertilizing sole crop maize for high yields. Samaru Miscellanous paper, 76, Institute for Agricultural Research, Ahmadu Bello University, Zaria, Nigeria.

Chiezey, U. F. (1999). Effects of magnesium and zinc Fertilizers on the yield and yield components of soybean (Glycine max (L.) Merrill) in the northern Guinea Savanna of Nigeria. Tropical Oilseeds Journal, 4, 1-8.

Chiezey, U. F., \& Shamsndeen, R. (2004). Popcorn response to plant population dynamics and nitrogen levels in the northern Guinea Savanna zone of Nigeria. Journal of Agriculture and environment for international developments, 98(3), 211-222.

Duncan, D. B. (1955). Multiple ranges and Multiple ' $\mathrm{F}$ ' test. Biometrics, 11, 1-42. http://dx.doi.org/10.2307/3001478

Goldsworthy, P. R. (1967). Response of cereals to fertilizers in northern Nigeria. Experimental Agriculture, 3, 263-273. http://dx.doi.org/10.1017/S0014479700022158

Iwuafor, E. N. O., Chude, V. O., \& Amapu, I. (1991). Response of maize (Zea mays L.) to various rates of zinc fertilizer in the semi-arid zone of Nigeria. Paper presented at SAFGRAD Network Joint Workshop, Niamey, Niger Republic 8-14 March, pp 14.

Jaliya, M. M., Falaki, A. M., \& Mahmud, M. (2004). Effects of sowing date and NPK fertilizer on growth and yield of quality protein Maize in northern Guinea savanna of Nigeria. Unpublished M.Sc. Thesis, Department of Agronomy, Ahmadu Bello University, Zaria.

Jones, M. J. (1973). Time of application of nitrogen fertilizer to maize at Samaru, Nigeria. Experimental Agriculture, 9(2), 113-120. http://dx.doi.org/10.1017/S0014479700005573

Kowal, J. M., \& Knabe, D. T. (1972). An Agroclimatological Atlas of the nrothern states of Nigeria. Zaria: Ahmadu Bello University Press.

Lombin, G. (1983). Evaluation of the micronutrient fertility of Nigeria's savanna soils. Soil Science, 136, 42-47. http://dx.doi.org/10.1097/00010694-198307000-00006

Mbagwu, J. S. C. (1990). Maize response to N fertilizer under two tillage and mulch treatments. Journal of Science of Food and Agriculture, 52(3), 365-376. http://dx.doi.org/10.1002/jsfa.2740520309

Mengel, K., \& Kirkby, E. A. (1987). Principles of plant nutrition (No. Ed. 4). International Potash Institute.

Ologunde, O. O., \& Ogunlela, V. B. (1984). Relationship of Plant density and nitrogen fertilization to maize performance in the Nigerian southern Guinea savanna. Samaru Journal of Agricultural Research, 2, 99-109.

Osiname, O. A. (1972). Soil test for available copper and zinc in soils of western Nigeria. Ph.D Thesis, University of Wisconsin, Madison.

Snodecor, G. W., \& Cochran, W. G. (1962). Statistical Methods (6th ed.). Iowa State University Press, Ames.

\section{Copyrights}

Copyright for this article is retained by the author(s), with first publication rights granted to the journal.

This is an open-access article distributed under the terms and conditions of the Creative Commons Attribution license (http://creativecommons.org/licenses/by/3.0/). 